\title{
PENGARUH EKSTRAK ETANOLIK BUAH PARIJOTO (Medinilla speciosa Blume) TERHADAP KADAR GULA DARAH DAN FUNGSI SEKSUAL TIKUS JANTAN GALUR WISTAR MODEL DIABETES MELLITUS KRONIK
}

\author{
Rina Wijayanti ${ }^{* 1)}$, Asih Puji Lestari ${ }^{2)}$ \\ 1,2 Program Studi Farmasi Fakultas Kedokteran Universitas Islam Sultan Agung \\ Semarang Jalan Kaligawe KM 4 Semarang 50012 Telp (+6224) 6583584 Fax (+6224) 6594366 \\ Email:wijayanti@unissula.ac.id
}

\section{INTISARI}

Diabetes Mellitus kronik merupakan penyakit meningkatnya kadar gula darah dalam kurun waktu lama sehingga dapat mempengaruhi fungsi seksual di antaranya merusak spermatogenesis dan fungsi afrodisiak. EEBP memiliki kandungan flavonoid. Tujuan dari penelitian ini untuk mengetahui pengaruh EEBP terhadap kadar gula darah dan fungsi seksual tikus jantan galur wistar model Diabetes Mellitus kronik. Penelitian dilakukan dengan rancangan post test only control group design, menggunakan 25 ekor tikus jantan galur wistar usia 2 bulan dengan BB 100-200 gram terbagi 5 kelompok. Kelompok 1 (kontrol normal), kelompok 2 (kontrol negatif) diinduksi aloksan $100 \mathrm{mg} / \mathrm{kgBB}$, kelompok 3,4, dan 5 yaitu diinduksi aloksan dan diberikan EEBP dengan dosis $100 \mathrm{mg} / \mathrm{kgBB}, 250 \mathrm{mg} / \mathrm{kgBB}$, dan $500 \mathrm{mg} / \mathrm{kgBB}$. Tikus yang diinduksi aloksan dibiarkan selama 4 minggu untuk mencapai DM kronik. Analisa data kadar glukosa darah dan kualitas spermatozoa menggunakan one way anova dilanjut pos hoc LSD. Sedangkan afrodisiak yaitu introducing dan climbing menggunakan one way anova dilanjut LSD dan Coitus menggunakan kruskal wallis. Hasil penelitian menunjukkan terdapat perbedaan bermakna antara kontrol negatif dengan kelompok normal, III, IV, dan V. Pengaruh pemberian ekstrak etanolik buah parijoto terhadap kadar gula darah dan fungsi seksual pada tikus jantan galur wistar yang diinduksi aloksan menunjukan tidak terdapat perbedaan antara kelompok perlakuan dosis $100 \mathrm{mg} / \mathrm{kgBB}$ dengan kelompok negatif, dan terdapat perbedaan yang signifikan antara kelompok perlakuan dosis $250 \mathrm{mg} / \mathrm{kgBB}$ dan $500 \mathrm{mg} / \mathrm{kgBB}$ dengan kelompok negatif. Kesimpulan yang diambil bahwa Ekstrak etanolik buah parijoto pada dosis $250 \mathrm{mg} / \mathrm{kgBB}$ dan $500 \mathrm{mg} / \mathrm{kgBB}$ mampu menurunkan kadar gula darah dan meningkatkan fungsi seksual pada tikus jantan galur wistar model DM kronik.

Kata kunci: Ekstrak Etanolik Buah Parijoto, Kadar Glukosa Darah, Fungsi Seksual.

\begin{abstract}
Chronic diabetes mellitus is a disease of increased blood glucose levels in a long time so that it can affect sexual function such as damage spermatogenesis and aphrodisiac function. Parijoto has flavonoid content. This study aimed to determine the effect of ethanolic extract of parijoto (Medinilla speciosa Blume) fruit in blood glucose level and the sexual function in alloxan-induced diabetic male rats. The design of the study was post test only control group design, 25 male wistar rats aged 2 months with BB 100-200 gram divided into 5 groups. Group 1 (normal control), group 2 (negative control) induced alloxan 100mg / $\mathrm{kgBB}$, groups 3, 4, and 5 were alloxan induced and administered EEBP at doses of $100 \mathrm{mg} / \mathrm{kgBW}, 250 \mathrm{mg} /$ $\mathrm{kgBW}$, and $500 \mathrm{mg} / \mathrm{kgBW}$. Alloxan-induced rats were left for 4 weeks to achieve chronic DM. Data analysis of blood glucose level and spermatozoa quality using one way anova followed by LSD post hoc. While aphrodisiac of introducing and climbing using one way anova continued by LSD and coitus using kruskal wallis. The results showed that there were significant differences between negative control with normal group, III, IV, and V. The effect of ethanolic extract of parijoto fruit on blood glucose level and sexual function in alloxan-induced diabetic male rats showed no difference between treatment group of 100 $\mathrm{mg} / \mathrm{kgBW}$ with negative group, and there were significant differences between treatment group of $250 \mathrm{mg} /$ $\mathrm{kgBW}$ and $500 \mathrm{mg} / \mathrm{kgBW}$ with negative group. Ethanolic extract of parijoto fruit at dose $250 \mathrm{mg} / \mathrm{kgBB}$
\end{abstract}


and $500 \mathrm{mg} / \mathrm{kgBB}$ decrease blood glucose level, improve and increase sexual function in alloxan-induced diabetic male rats.

Keywords: Ethanolic Extract of Parijoto Fruit, Blood Glucose Level, Sexual Function

Corresponding author:

Rina Wijayanti

Program Studi Farmasi Fakultas Kedokteran Universitas Islam Sultan Agung

Semarang Jalan Kaligawe KM 4 Semarang 50012 Telp (+6224) 6583584 Fax (+6224) 6594366

Email: wijayanti@unissula.ac.id

\section{PENDAHULUAN}

Tanaman yang sering digunakan secara empiris untuk meningkatkan kesuburan adalah buah Parijoto. Parijoto (Medinilla speciosa Blume) adalah salah satu spesies dari familia Melastomataceae, merupakan salah satu tanaman khas dari Desa Colo Kecamatan Dawe Kabupaten Kudus Jawa Tengah. Oleh masyarakat setempat, buah Parijoto digunakan secara turun temurun untuk terapi kesuburan bagi pasutri yang menginginkan keturunan.

Telah dilaporkan beberapa jenis tumbuhan famili Melastomataceae yang memiliki aktivitas sebagai antioksidan seperti Melastoma malabathrium (Wachidah, 2013). Kandungan dalam daun dan buah parijoto terdapat saponin dan kardenolin, di samping itu buahnya juga mengandung flavonoid dan daunnya mengandung tannin (Anonim, 2017). Senyawa saponin dan flavonoid memiliki aktivitas afrodisiaka (Indrisari, dkk, 2014). Berdasarkan penelitian terhadap tanaman yang berpotensi sebagai afrodisiaka, adanya kandungan flavonoid yang berkhasiat sebagai antioksidan mampu mempertahankan motilitas sperma (Musfirah, dkk, 2016). Flavonoid juga diketahui memiliki aktivitas farmakologis untuk menurunkan kadar gula darah, seperti yang terkandung pada Ekstrak etanolik buah parijoto yang terbukti mampu menurunkan kadar glukosa darah (Wijayanti dan Rosyid, 2015). Penelitian yang dilakukan oleh Kumar, dkk (2013) menyatakan bahwa daun Melastoma malabathrium Linn yang merupakan familia Melastomataceae pada dosis $100 \mathrm{mg} / \mathrm{kg} \mathrm{BB}, 250 \mathrm{mg} / \mathrm{kg} \mathrm{BB}$, dan $500 \mathrm{mg} / \mathrm{kg}$ BB mempunya aktivitas sebagai Antidiabetik.

Bukti ilmiah tentang pengaruh Ekstrak Etanolik Buah Parijoto (Medinilla speciosa Blume) terhadap kadar gula darah dan fungsi seksual tikus jantan galur wistar model Diabetes Mellitus belum banyak dilaporkan. Berdasarkan latar belakang tersebut maka dilakukan penelitian secara ilmiah untuk membuktikan manfaat ekstrak buah parijoto terhadap penurunan kadar gula darah dan fungsi seksual tikus jantan galur wistar model DM.

\section{METODE PENELITIAN}

Bahan Penelitian

Bahan yang digunakan dalam penelitian ini adalah buah parijoto yang diperoleh dari lereng Gunung Muria Kudus, larutan CMC Na, larutan eosin-nigrosin, etanol 70\%, aloksan, aquadest, pelet.

\section{Alat Penelitian}

Alat yang digunakan dalam penelitian ini meliputi seperangkat alat untuk ekstraksi, seperangkat alat uji kadar glukosa darah, mikroskop dan optilab, bilik hitung Neubauer dan pipet leukosit.

\section{JALANNYA PENELITIAN}

\section{Pembuatan Ekstrak Etanol Buah Parijoto}

Pembuatan ekstrak etanol buah parijoto dilakukan dengan cara maserasi menggunakan pelarut etanol $70 \%$ dengan perbandingan antara simplisia halus dan pelarut adalah 1:10, kemudian dilakukan ekstraksi dengan cara maserasi selama 3 hari dengan pengulangan (remaserasi) setiap $1 \mathrm{x}$ 24 jam sebanyak 3 kali (Maghfiroh, 2015).

\section{Penyiapan Hewan Uji}

Sebanyak 35 dibagi dalam 5 kelompok. Kelompok I adalah kelompok base line (normal), kelompok II adalah kelompok kontrol negatif, kelompok III, IV, dan V adalah kelompok perlakuan 
pemberian EEBP (Ekstrak Etanolik Buah Parijoto) masing-masing dengan dosis $100 \mathrm{mg} / \mathrm{kgBB}$, $250 \mathrm{mg} / \mathrm{kgBB}$, dan $500 \mathrm{mg} / \mathrm{kg} \mathrm{BB}$.

\section{Penyiapan Bahan Diabetogenik}

Bahan diabetogenik yang digunakan yaitu aloksan. Tikus terlebih dahulu dipuasakan selama 16 jam kemudian diinjeksi aloksan dengan dosis $100 \mathrm{mg} / \mathrm{kg}$ BB secara intraperitoneal. Setelah diinduksi aloksan, tikus dibiarkan selama 4 minggu untuk mencapai kondisi kronis (Nur'aini, 2014).

\section{Pengukuran Kadar Gula Darah}

Pengukuran kadar glukosa darah dilakukan pada waktu sebelum diinduksi aloksan, hari ke 3, dan setiap minggu selama 4 minggu sesudah diinduksi aloksan. Tikus dipuasakan selama 16 jam terlebih dahulu sebelum diukur glukosa darahnya. Pengukuran kadar glukosa darah menggunakan alat yaitu glukotest, darah yang dikur adalah darah dari pembuluh darah ekor tikus. Tikus dinyatakan diabetes jika kadar glokosa darahnya lebih dari 200 mg/dl (Kumar, dkk, 2013).

\section{Pengujian Pengaruh Ekstrak Etanolik Buah Parijoto}

EEBP diberikan selama 4 minggu setelah tikus dibiarkan mengalami diabetes melitus kronik (4 minggu pasca induksi aloksan) (Nur'aini, 2014 dan Kumar, dkk, 2013). Pemberian EEBP dilakukan secara oral menggunakan sonde lambung. Pada akhir penelitian, tikus dipuasakan selama 16 jam dan diamati untuk mengetahui pengaruh EEBP terhadap :

\section{a. Kadar Glukosa Darah}

Pengukuran kadar glukosa dilakukan dengan mengambil sampel darah vena orbitalis mata tikus. Diambil sebanyak $1 \mathrm{ml}$ sampel darah dan ditampung ke dalam tube.Kemudian darah yang sudah diambil disentrifuge dengan kecepatan 4000 putaran permenit selama 15 menit untuk memisahkan serum dan plasma darah. Serum yang sudah terpisah diambil sebanyak $10 \mu 1$ dan dicampur dengan $1000 \mu \mathrm{l}$ glukosa kit di dalam tabung reaksi kemudian di vortex selama 1 menit dan diinkubasi pada suhu 30oC selama 20 menit. Kemudian dibaca absorbansi pada panjang gelombang $500 \mathrm{~nm}$.

\section{b. Afrodisiak}

Tikus jantan diberikan ekstrak etanolik buah parijoto sebanyak satu kali sehari selama 14 hari secara per oral. Pengujian pengaruh afrodisiak dilakukan pada hari ke-15 setelah pemberian ekstrak. Pada malam hari, masing-masing 1 ekor tikus betina dimasukkan ke dalam kandang yang sudah terdapat 1 ekor tikus jantan selama 1 jam (Sarapi, 2015). Tikus betina dibuat reseptif (estrus) dengan pemberian subkutan $10 \mu \mathrm{g} / 100 \mathrm{~g}$ berat badan estradiol benzoat dan 0,5 $\mathrm{mg} /$ $100 \mathrm{~g}$ berat badan progesteron, 48 jam dan 4 jam, sebelum dipasangkan dengan tikus jantan (Yakubu \& Akanji, 2011). Tahap estrus pada tikus betina ditandai dengan pembengkakan dan perubahan warna vulva vagina menjadi lebih merah dari sebelumnya (Sukmaningsih et al, 2017).

c. Kualitas Sperma

Tikus jantan diambil spermatozoanya pada bagian cauda epidedimis menggunakan pipet leukosit dan diencerkan 20x dengan $\mathrm{NaCl} 0,9 \%$ (suspensi spermatozoa), kemudian diamati kualitasnya melalui parameter jumlah dan viabilitas.

\section{ANALISIS DATA}

Data hasil pengukuran kadar glukosa darah dan kualitas sperma (jumlah dan viabilitas) dilakukan uji normalitas dan uji homogenitas dan dilanjutkan dengan uji parametrik one way anova dan dilanjut LSD. Data hasil ICC untuk introducing dan climbing menggunakan one way anova dilanjut LSD dan coitus menggunakan kruskal wallis.

\section{HASIL PENELITIAN}

Penelitian dilakukan pada bulan Desember 2017 sampai dengan bulan Februari 2018. Penelitian bertempat di Laboratorium Farmasi dan Laboratorium Biologi Fakultas Kedokteran Universitas Islam Sultan Agung.

1. Pengukuran kadar glukosa darah pada tikus jantan galur wistar dilakukan setelah pemberian suspensi ekstrak buah parijoto selama 14 hari. Pengambilan darah dilakukan di bagian vena orbitalis mata. Darah disentrifuge untuk memisahkan serum dan plasma. Serum yang telah 
didapat ditambahkan pereaksi glukosa kit kemudian dilakukan pengecekan dengan metode spektrofotometri. Tabel hasil pengukuran kadar gula darah tersaji pada Tabel 1.

Tabel 1. Hasil Pengukuran Kadar Glukosa Darah dengan Metode Spektrofotometri

\begin{tabular}{cccccc}
\hline \multirow{2}{*}{$\begin{array}{c}\text { No } \\
\text { Sampel }\end{array}$} & $\begin{array}{c}\text { Kontrol } \\
\text { Normal }\end{array}$ & $\begin{array}{c}\text { Kontrol } \\
\text { Negatif }\end{array}$ & $\begin{array}{c}\text { Dosis } \\
\text { 100mg/KgBB }\end{array}$ & $\begin{array}{c}\text { Dosis } \\
\mathbf{2 5 0 m g / K g B B}\end{array}$ & $\begin{array}{c}\text { Dosis } \\
\mathbf{5 0 0 m g / K g B B}\end{array}$ \\
\hline 1 & 98 & 178 & 126 & 136 & 96 \\
2 & 91 & 186 & 162 & 160 & 103 \\
3 & 79 & 162 & 142 & 123 & 101 \\
4 & 91 & 182 & 141 & 137 & 98 \\
5 & 112 & 153 & 138 & 116 & 106 \\
\hline Rata-Rata & $\mathbf{9 4 , 2}$ & $\mathbf{1 7 2 , 2}$ & $\mathbf{1 4 1 , 8}$ & $\mathbf{1 3 4 , 4}$ & $\mathbf{1 0 0 , 8}$ \\
\hline SD & $\mathbf{1 2 , 0 7 0 6}$ & $\mathbf{1 4 , 0 7 8 4}$ & $\mathbf{1 2 , 9 6 9 2}$ & $\mathbf{1 6 , 8 3 1 5}$ & $\mathbf{3 , 9 6 2 3}$ \\
\hline
\end{tabular}

2. Afrodisiak

Tabel 2. Frekuensi Introduction

\begin{tabular}{cccccc}
\hline \multirow{2}{*}{$\begin{array}{c}\text { No } \\
\text { Sampel }\end{array}$} & Normal & $\begin{array}{c}\text { Kontrol } \\
\text { Negatif }\end{array}$ & $\begin{array}{c}\text { Dosis } \\
\text { 100mg/KgBB }\end{array}$ & $\begin{array}{c}\text { Dosis } \\
\mathbf{2 5 0 m g / K g B B}\end{array}$ & $\begin{array}{c}\text { Dosis } \\
\mathbf{5 0 0 m g / K g B B ~}\end{array}$ \\
\hline 1 & 14 & 6 & 12 & 12 & 11 \\
2 & 12 & 6 & 7 & 9 & 9 \\
3 & 9 & 5 & 10 & 6 & 12 \\
4 & 15 & 4 & 8 & 8 & 14 \\
5 & 13 & 8 & 6 & 6 & 15 \\
\hline Rata-rata & $\mathbf{1 2 , 6}$ & $\mathbf{5 , 8}$ & $\mathbf{8 , 6}$ & $\mathbf{8 , 2}$ & $\mathbf{1 2 , 2}$ \\
\hline SD & $\mathbf{2 , 3}$ & $\mathbf{1 , 3}$ & $\mathbf{2 , 1}$ & $\mathbf{2 , 2}$ & $\mathbf{2 , 3}$ \\
\hline
\end{tabular}

Dari uji normalitas nilai p kelompok $1=0,685$, kelompok $2=0,777$, kelompok $3=0,787$, kelompok 4=0,384, dan kelompok 5=0,899. Uji homogenitas diperoleh nilai $\mathrm{p}=0,774(\mathrm{p}>0,05)$. Hasil uji One Way Anova diperoleh nilai $\mathrm{p}=0,000(\mathrm{p}<0,05)$.

Tabel 3. Frekuensi Climbing

\begin{tabular}{cccccc}
\hline & \multicolumn{5}{c}{ Frekuensi Climbing (kali) } \\
\cline { 2 - 6 } $\begin{array}{c}\text { No } \\
\text { Sampel }\end{array}$ & Normal & $\begin{array}{c}\text { Kontrol } \\
\text { Negatif }\end{array}$ & $\begin{array}{c}\text { Dosis } \\
\text { 100mg/KgBB }\end{array}$ & $\begin{array}{c}\text { Dosis } \\
\text { 250mg/KgBB }\end{array}$ & $\begin{array}{c}\text { Dosis } \\
\mathbf{5 0 0 m g / K g B B ~}\end{array}$ \\
\hline 1 & 6 & 3 & 5 & 5 & 7 \\
2 & 7 & 4 & 5 & 3 & 4 \\
3 & 7 & 2 & 4 & 4 & 5 \\
4 & 5 & 2 & 3 & 8 & 10 \\
5 & 9 & 3 & 2 & 7 & 9 \\
\hline Rata-rata & $\mathbf{6 , 8}$ & $\mathbf{2 , 8}$ & $\mathbf{3 , 8}$ & $\mathbf{5 , 4}$ & $\mathbf{7 , 0}$ \\
\hline SD & $\mathbf{1 , 4}$ & $\mathbf{0 , 8}$ & $\mathbf{1 , 3}$ & $\mathbf{2 , 0}$ & $\mathbf{2 , 5}$ \\
\hline
\end{tabular}

Dari uji normalitas nilai p kelompok $1=0,777$, kelompok $2=0,314$, kelompok $3=0,421$, kelompok 4=0,754, dan kelompok $5=0,692$. Hasil uji homogenitas diperoleh nilai $\mathrm{p}=0,125$ ( $p>0.05)$.Hasil uji One Way Anova diperoleh nilai $\mathrm{p}=0,004(\mathrm{p}<0,05)$. 
Tabel 4. Frekuensi Coitus

\begin{tabular}{cccccc}
\hline & \multicolumn{5}{c}{ Frekuensi Coitus (kali) } \\
\cline { 2 - 6 } $\begin{array}{c}\text { No } \\
\text { Sampel }\end{array}$ & Normal & $\begin{array}{c}\text { Kontrol } \\
\text { Negatif }\end{array}$ & $\begin{array}{c}\text { Dosis } \\
\text { 100mg/KgBB }\end{array}$ & $\begin{array}{c}\text { Dosis } \\
\text { 250mg/KgBB }\end{array}$ & $\begin{array}{c}\text { Dosis } \\
\mathbf{5 0 0 m g / K g B B ~}\end{array}$ \\
\hline 1 & 1 & 0 & 1 & 0 & 0 \\
2 & 1 & 0 & 0 & 0 & 0 \\
3 & 1 & 0 & 0 & 0 & 1 \\
4 & 1 & 0 & 0 & 1 & 1 \\
5 & 1 & 0 & 0 & 0 & 1 \\
\hline Rata-rata & $\mathbf{1}$ & $\mathbf{0}$ & $\mathbf{0 , 2}$ & $\mathbf{0 , 2}$ & $\mathbf{0 , 6}$ \\
\hline SD & $\mathbf{0}$ & $\mathbf{0}$ & $\mathbf{0 , 4}$ & $\mathbf{0 , 4}$ & $\mathbf{0 , 5}$ \\
\hline
\end{tabular}

Dari uji normalitas nilai $\mathrm{p}$ kelompok $3=0,000$, kelompok $4=0,000$, dan kelompok $5=0,000$ $(\mathrm{p}<0,005)$. Hasil uji homogenitas diperoleh nilai $\mathrm{p}=0,025(\mathrm{p}<0.05)$.Hasil uji Kruskal Wallis diperoleh nilai $\mathrm{p}=0,005(\mathrm{p}<0,05)$.

3. Kualitas Spermatozoa

Tabel 5. Hasil Jumlah Spermatozoa

\begin{tabular}{cccccc}
\hline \multirow{2}{*}{$\begin{array}{c}\text { No } \\
\text { Sampel }\end{array}$} & \multicolumn{5}{c}{ Jumlah Spermatozoa (juta/mL) } \\
\cline { 2 - 6 } & $\begin{array}{c}\text { Kontrol } \\
\text { Normal }\end{array}$ & $\begin{array}{c}\text { Kontrol } \\
\text { Negatif }\end{array}$ & $\begin{array}{c}\text { Dosis Ekstrak } \\
\text { 100mg/KgBB }\end{array}$ & $\begin{array}{c}\text { Dosis Ekstrak } \\
\text { 250mg/KgBB }\end{array}$ & $\begin{array}{c}\text { Dosis Ekstrak } \\
\text { 500mg/KgBB }\end{array}$ \\
\hline 1 & 25,1 & 7,85 & 11,45 & 17,35 & 20,2 \\
2 & 32 & 9,95 & 8,5 & 7,5 & 22,1 \\
3 & 24,95 & 10,15 & 14,85 & 16,1 & 20,85 \\
4 & 22,25 & 10,4 & 13,4 & 16,65 & 25,1 \\
5 & 25,65 & 8,7 & 13,5 & 10,25 & 23,75 \\
\hline Rata-rata & $\mathbf{2 5 , 9 9}$ & $\mathbf{9 , 4 1}$ & $\mathbf{1 2 , 3 4}$ & $\mathbf{1 3 , 5 7}$ & $\mathbf{2 2 , 4}$ \\
\hline SD & $\mathbf{3 , 6 0}$ & $\mathbf{1 , 0 9}$ & $\mathbf{2 , 4 6}$ & $\mathbf{4 , 4 1}$ & $\mathbf{2 , 0 2}$ \\
\hline
\end{tabular}

Dari uji normalitas nilai p kelompok $1=0,190$, kelompok $2=0,305$, kelompok $3=0,496$, kelompok 4=0,162, dan kelompok 5=0,751. Uji homogenitas diperoleh nilai $\mathrm{p}=0,056(\mathrm{p}>0,05)$. Hasil uji One Way Anova diperoleh nilai p=0,000 (p<0,05).

Tabel 6. Hasil Viabilitas Spermatozoa

\begin{tabular}{cccccc}
\hline \multirow{2}{*}{$\begin{array}{c}\text { No } \\
\text { Sampel }\end{array}$} & Kontrol & $\begin{array}{c}\text { Kontrol } \\
\text { Normal }\end{array}$ & $\begin{array}{c}\text { Dosiabilitas Skstrak } \\
\text { Negatif }\end{array}$ & $\begin{array}{c}\text { Do0 mg/KgB Ekstrak } \\
\mathbf{2 5 0} \mathbf{~ m g / K g B B}\end{array}$ & $\begin{array}{c}\text { Dosis Ekstrak } \\
\mathbf{5 0 0} \mathbf{~ m g / K g B B}\end{array}$ \\
\hline 1 & 77,01 & 36,96 & 36,16 & 42,49 & 68,23 \\
2 & 81,09 & 32,55 & 38,85 & 27,17 & 73,46 \\
3 & 77,14 & 25,90 & 45,45 & 50,82 & 75,42 \\
4 & 91,25 & 18,50 & 43,91 & 60,63 & 61,30 \\
5 & 90,59 & 31,46 & 32,80 & 58,03 & 67,74 \\
Rata-rata & $\mathbf{8 3 , 4 2}$ & $\mathbf{2 9 , 0 7}$ & $\mathbf{3 9 , 4 4}$ & $\mathbf{4 7 , 8 3}$ & $\mathbf{6 9 , 2 3}$ \\
SD & $\mathbf{7 , 0 4}$ & $\mathbf{7 , 1 0}$ & $\mathbf{5 , 2 7}$ & $\mathbf{1 3 , 5 2}$ & $\mathbf{5 , 5 2}$ \\
\hline
\end{tabular}

Dari uji normalitas nilai p kelompok $1=0,103$, kelompok $2=0,763$, kelompok $3=0,731$, kelompok 4=0,546, dan kelompok 5=0,719. Uji homogenitas diperoleh nilai $\mathrm{p}=0,126(\mathrm{p}>0,05)$. Hasil uji One Way Anova diperoleh nilai p=0,000 (p<0,05). 


\section{PEMBAHASAN}

Penelitian ini menggunakan buah parijoto yang sudah tua berwarna keunguan dari perkebunan di desa Colo, Kecamatan Dawe, Kabupaten Kudus. Buah parijoto yang telah kering dan halus diekstraksi menggunakan metode maserasi dengan pelarut yaitu etanol $70 \%$ dan dilakukan pengulangan (remaserasi) sebanyak tiga kali.

Model tikus DM kronis dilakukan dengan cara induksi aloksan secara intraperitoneal. Untuk memperoleh DM kronis tikus dibiarkan selama 28 hari pasca induksi aloksan (Nuraini, 2014). Aloksan diberikan dengan dosis $100 \mathrm{mg} / \mathrm{KgBB}$ pada hewan uji. Aloksan mampu merusak sel-sel $\beta$ pankreas sehingga pankreas mengalami gangguan dalam memproduksi insulin. Efek dari pemberian aloksan yaitu kadar glukosa darah meningkat yang mirip pada manusia yang menderita DM (Yuriska, 2009). Pemberian ekstrak dilakukan setelah tikus mengalami kondisi diabetes melitus kronis pada minggu keempat selama 14 hari dan

Pengecekan Kadar Gula Darah. kadar glukosa darah tikus dilakukan pengecekan tiap minggunya. Hasil analisis data menggunakan oneway anova didapatkan hasil nilai $\mathrm{p}=0,000$ yang berarti terdapat pengaruh ekstrak etanolik buah perijoto terhadap kadar glukosa darah yang berbeda signifikan kemudian dilanjutkan uji post hoc untuk mengetahui perbedaan antar kelompok. Hasil uji Post Hoc didapatkan hasil pada kelompok kontrol normal dengan kontrol negatif terdapat perbedaan yang signifikan. Perbandingan antara kelompok negatif dengan kelompok Dosis 100 $\mathrm{mg} / \mathrm{KgBB}$, Kelompok dosis $250 \mathrm{mg} / \mathrm{KgBB}$ dan kelompok dosis $500 \mathrm{mg} / \mathrm{KgBB}$ menunjukkan adanya perbedaan yang signifikan. Hal ini menunjukkan pemberian ekstrak yang dilakukan selama 14 hari terbukti mampu menurunkan kadar glukosa darah pada hewan uji. Hal tersebut mengindikasikan bahwa ekstrak etanolik buah parijoto dengan dosis $500 \mathrm{mg} / \mathrm{KgBB}$ memiliki aktivitas antidiabetes dan mampu mengembalikan kadar glukosa darah pada keadaan normal.

Frekuensi Introduction. Perbandingan antara kelompok kontrol negatif dengan dosis $100 \mathrm{mg} / \mathrm{KgBB}$ dan dosis $250 \mathrm{mg} / \mathrm{KgBB}$ diperoleh nilai $\mathrm{p}>0,05$ yang berarti bahwa pada dosis $100 \mathrm{mg} / \mathrm{KgBB}$ dan $250 \mathrm{mg} / \mathrm{KgBB}$ tidak didapati pengaruh yang signifikan. Perbandingan antara kelompok kontrol negatif dengan dosis $500 \mathrm{mg} / \mathrm{KgBB}$ diperoleh nilai $\mathrm{p}$ sebesar $0,000(\mathrm{p}<0,05)$ yang berarti pada dosis $500 \mathrm{mg} / \mathrm{KgBB}$ didapati pengaruh yang signifikan dalam meningkatkan nilai introduction. Hal ini menunjukkan bahwa kandungan ekstrak etanolik buah parijoto seperti flavonoid memiliki potensi dalam meningkatkan gairah seksual.

Frekuensi Climbing. Perbandingan antara kelompok kontrol negatif dengan dosis $100 \mathrm{mg} / \mathrm{KgBB}$ diperoleh $\mathrm{p}$ sebesar 0,387 ( $>0,05)$ sehingga pada dosis $100 \mathrm{mg} / \mathrm{KgBB}$ tidak didapati pengaruh yang signifikan terhadap peningkatan nilai climbing. Perbandingan antara kelompok kontrol negatif dengan dosis $250 \mathrm{mg} / \mathrm{KgBB}$ dan $500 \mathrm{mg} / \mathrm{KgBB}$ diperoleh nilai $\mathrm{p}<0,05$ yang berarti pada kedua dosis tersebut didapati pengaruh yang signifikan terhadap peningkatan nilai tunggangan (climbing).

Frekuensi Coitus. Perbandingan antara kelompok kontrol negatif dengan dosis $100 \mathrm{mg} / \mathrm{KgBB}$ dan dosis $250 \mathrm{mg} / \mathrm{KgBB}$ diperoleh nilai $\mathrm{p}>0,05$ yang berarti bahwa pada dosis $100 \mathrm{mg} / \mathrm{KgBB}$ dan dosis $250 \mathrm{mg} / \mathrm{KgBB}$ tidak didapati pengaruh yang signifikan terhadap peningkatan nilai coitus. Perbandingan antara kelompok kontrol negatif dengan dosis $500 \mathrm{mg} / \mathrm{KgBB}$ diperoleh nilai $\mathrm{p}$ sebesar $0,014(\mathrm{p}<0,05)$ yang berarti bahwa pada dosis $500 \mathrm{mg} / \mathrm{KgBB}$ didapati pengaruh yang signifikan terhadap peningkatan nilai coitus.

Kualitas Spematozoa. Pengamatan kualitas sperma ditinjau dari jumlah dan viabilitas sperma. Jumlah spermatozoa perbandingan antara kelompok negatif dan dosis $100 \mathrm{mg} / \mathrm{kgBB}$ diperoleh nilai $\mathrm{p}>0,05$ maka pada dosis $100 \mathrm{mg} / \mathrm{kgBB}$ tidak didapati pengaruh terhadap peningkataan jumlah spermatozoa. Sedangkan perbandingan antara kelompok megatif dan dosis $250 \mathrm{mg} / \mathrm{kgBB}$ dan dosis $500 \mathrm{mg} / \mathrm{kgBB}$ diperoleh nilai $\mathrm{p}<0,05$ maka didapati pengaruh terhadap peningkatan kualitas spermatozoa. Hal tersebut sama seperti viablilitas spermatozoa bahwa pada dosis $250 \mathrm{mg} / \mathrm{kgBB}$ dan dosis $500 \mathrm{mg} / \mathrm{kgBB}$ didapati pengaruh terhadap peningkatan kualitas spermatozoa. 


\section{KESIMPULAN}

Ekstrak Etanolik Buah Parijoto (Medinilla speciosa Blume) terbukti memiliki efektivitas penurunan kadar glukosa darah, efektivitas afrodisiak dan kualitas spermatozoa pada tikus jantan galur wistar model diabetes melitus kronik.

\section{SARAN}

Perlunya dilakukan pengecekan kadar testosteron dan uji histologi pada testis.

\section{DAFTAR PUSTAKA}

Suyono, S., 2005, Kecenderungan Peningkatan Jumlah Penyandang Diabetes, Jakarta : Balai Penerbit Fakultas Kedokteran Universitas Indonesia.

Wachidah, L. N, 2013, Uji Aktivitas Antioksidan serta Penentuan Kandungan Fenolat dan Flavonoid Total dari Buah Pajijoto (Medinilla speciosa Blume), Skripsi, Fakultas Kedokteran dan Ilmu Kesehatan Program Studi Farmasi Universitas Islam Negeri Syarif Hidayatullah Jakarta.

Anonim,2017,http://www.warintek.ristek.go.id/pangan_kesehatan/tanaman_obat/depkes/5-062.pdf. Diakses pada tangal 22 Mei 2017.

Indrisari, M., Rahimah, S., Umar, A. H., Allyah, A. P., 2014, Uji Efek Afrodisiaka dari Ekstrak Bawang Putih (Allium sativum) pada Hewan Coba Mencit (Mus musculus), Akademi Farmsi Kebangsaan dan Sekolah Tinggi Ilmu Farmasi.

Kumar, V., Ahmed, D., Gupta, P. S., Anwar, F., Mujeeb, M., 2013, Anti-diabetic, Anti-oidant and Anti-hyperlipidemic Activities of Melastoma malabathricum Linn. Leaves in Streptozotocin induced Diabetic Rats, BioMed Central Complementary \& Alternative Medicine, Vol $13: 222$

Musfirah, Y., Bachri, M. S., Nurani, L. H., 2016, Potensi Ekstrak Etanol 70\% Akar Saluang Balum (Lavanga sarmentosa Blume kurtz) terhadap Kualitas dan Viabilitas Sperma Mencit, Pharmaciana, Vol 6 (2) : 131-138.

Wijayanti, R., Rosyid, A., 2015, Efek Ekstrak Kulit Umbi Bawang Putih (Allium sativum L.) terhadap Penurunan Kadar Glukosa Darah pada Tikus Putih Jantan Galur Wistar yang Diinduksi Aloksan, Jurnal Ilmu Farmasi \& Farmasi Klinik, Vol 12 (1).

Nur'aini, F. D., 2014, Pengaruh Infusa Daun Murbei (Morus alba L.) terhadap Gambaran Histologi dan Berat Testis Tikus Putih (Rattus norvegicus) Diabetes Mellitus Kronil, Skripsi, Fakultas Kedokteran dan Ilmu Kesehatan Program Studi Farmasi Universitas Islam Negeri Syarif Hidayatullah Jakarta.

Sukmaningsih, A.A.S.A., Ida Bagus W.G., Nyoman S.A., Pande Ketut D.K., I Wayan Widia. 2017. Rebung Bambu Tabah (Gigantochloa Nigrociliata) Berpotensi Sebagai Bahan Afrodisiak pada Mencit Jantan. Jurnal Veteriner Vol.18 No.3.ISSN: 14118327; eISSN: 2477-5665.

Yakubu MT, Akanji MA, 2011. Effect of Aqueous Extract of Massularia acuminata Stem on Sexual Behaviour of Male Wistar Rats.Evidence-Based Complementary and Alternative Medicine.Department of Biochemistry, University of Ilorin, Nigeria. 